\title{
Problems with GH assays and strategies toward standardization
}

\author{
Martin Bidlingmaier \\ Endocrine Research Laboratories, Medizinische Klinik, Innenstadt, Ludwig-Maximilians University, Ziemssenstreet 1, 80336 Munich, Germany \\ (Correspondence should be addressed to M Bidlingmaier; Email: martin.bidlingmaier@med.uni-muenchen.de)
}

\begin{abstract}
Disorders affecting GH secretion - either GH deficiency or GH excess (acromegaly) - are biochemically defined through peak or nadir concentrations of human GH in response to dynamic tests. Immunoassays employing polyclonal or monoclonal antibodies are routinely used for the analysis of GH concentrations, and many different assays are available on the market today. Unfortunately, the actual value reported for the GH concentration in a specific patient's sample to a large extent depends on the assay method used by the respective laboratory. Variability between assay results exceeds $200 \%$, limiting the applicability of consensus guidelines in clinical practice. Reasons for the heterogeneity in GH assay results include the heterogeneity of the analyte itself, the availability of different preparations for calibration, and the interference from matrix components such as GH-binding protein. Furthermore, the reporting of results in mass units or international units together with the application of variable conversion factors led to confusion.

International collaborations proposed measures to improve the comparability of assay results, recommending the use of a single, recombinant calibrator for all assays and reporting only in mass units as first steps. However, because of the differences in epitope specificity of antibodies used in different assays, method-specific cut-off levels for dynamic tests might remain necessary to correctly interpret and compare results from different laboratories.
\end{abstract}

European Journal of Endocrinology 159 S41-S44

It is widely accepted that the diagnosis of a disease as well as the respective therapeutic decisions should be based on well-defined criteria, ideally based on evidence of best practice reflecting outcome of international efforts to establish guidelines and consensus documents. Accordingly, several consensus statements on diagnosis and treatment of GH-related disorders have been published (1-3). All these documents recommend the use of a biochemical definition within an appropriate clinical context for both GH deficiency and GH excess, with the biochemical definition being based on the measurements of $\mathrm{GH}$ concentrations during dynamic tests (stimulation or suppression) rather than in random samples. Interestingly, the consensus documents refer to published cut-off values for the interpretation of test outcome, but at the same time express concerns regarding the comparability of $\mathrm{GH}$ concentrations as measured by different assays. This might sound inconsistent, but reflects an existing dilemma: the weakness of the evidence bases behind many cut-off values to a large degree can be attributed to the discrepancy between the GH concentrations obtained from different assays (4-6). External quality

This paper was presented at the 5th Ferring International Paediatric Endocrinology Symposium, Baveno, Italy (2008). Ferring Pharmaceuticals has supported the publication of these proceedings. assessment schemes introduced in many countries to monitor the quality of laboratory testing unfortunately mainly document the continuation of disparity and the lack of standardization. Great variability in GH results from different assays has been reported from several countries by different laboratories participating in national external quality assessments (7-9). It is noteworthy that the disparity between $\mathrm{GH}$ assay results apparently worsened, especially with the introduction of newer assays based on monoclonal antibodies (10). The method-dependent variability exceeds $100 \%$ in many cases, making it impossible to compare results from one study with another or - relevant in clinical practice from one hospital to another when different laboratories are used.

Of course, the problem of standardization of immunoassays is not restricted to $\mathrm{GH}$ (11), but the measurement of GH involves a combination of classical problems: first, the analyte $\mathrm{GH}$ is not a homogenous molecule. On the contrary, GH in circulation consists of a wide variety of molecular isoforms $(12,13)$. Dimers of GH molecules occur, both as hetero- and homodimers, and also multimers are present in human serum (14). Consequently, as specific antibodies used in immunoassay recognize a specific epitope present on the surface of the antigen, each antibody will pick a selected spectrum of isoforms only. This spectrum is most likely broader for 
polyclonal antisera (representing a mixture of different antibodies) than for very specific monoclonal antibodies - which might explain the observation that discrepancy between assay results worsened with the introduction of assays based on monoclonal antibodies (10). Also in line with this, the best overall agreement between GH assays was found when the less specific, polyclonal antisera were used $(15,16)$. There is ongoing debate whether a more specific or a more permissive recognition of GH isoforms is preferable from a clinical point of view. Although a very specific assay based on monoclonal antibodies provides a better definition of what exactly is measured in a sample, different isoforms are biologically active (17). Therefore, we are potentially missing information with assays measuring only one isoform (5).

A second factor interfering with $\mathrm{GH}$ assays and contributing to discrepancy between results is the highaffinity GH-binding protein (GHBP), which circulates in human serum (18). It corresponds to the extracellular domain of the GH receptor, and its concentration varies with nutritional and metabolic conditions (19). In circulation, up to $50 \%$ of GH is complexed with GHBP, and therefore epitopes might not be accessible for certain antibodies due to steric hindrance. Potentially, this could lead to underestimation of $\mathrm{GH}$ concentrations. Especially, assays using monoclonal antibodies in conjunction with a very short incubation time (as in modern automated analyzers) are susceptible to interference from GHBP. The potential negative bias is considerable, approaching $50 \%$ in some assays for GHBP concentrations still in the physiological range (20-22).

A third important factor confounding the comparability of assay results is the standard preparation used to calibrate the assay. All immunoassays read the concentration of a hormone in the sample by comparing the signal generated in the sample with that generated by known amounts of the same hormone in the standard curve (calibrators). For GH assays, standard preparations of pituitary origin are widely used. These preparations (International Standard (IS) 66/217 introduced in 1969 and IS 80/505 introduced in 1982 therefore resemble a variety of $\mathrm{GH}$ isoforms, although the $22000 \mathrm{kDa}$ isoform is somewhat enriched. Because of the unknown 'true' GH content of the pituitary extracts, the concentrations were arbitrarily chosen at 2 and $2.6 \mathrm{U} / \mathrm{mg}$ respectively. More recently, the preparation IS $88 / 624$, which is recombinant $22000 \mathrm{kDa}$ GH only, was introduced and assigned to a biopotency of $3 \mathrm{U} / \mathrm{mg}$. IS $88 / 624$ was finally replaced by recombinant IS $98 / 574$. The latter preparation today is the reference material of choice to ensure traceability of $\mathrm{GH}$ assay results. Obviously, the change in the standard preparation has major influence on the absolute concentrations reported by different assays (9), with results getting generally lower compared with the previous - pituitary-derived - calibration. However, the conversion between the different units provides an additional source of problems in comparing $\mathrm{GH}$ assay results: depending on regional or national preferences, GH concentrations have been reported in units/l by some laboratories, but in $\mu \mathrm{g} / \mathrm{l}$ by others, with unclear conversion factors in many cases. The variety of standard preparations and units apparently led to considerable confusion among clinicians and scientists when reporting data from clinical studies in international journals. Pokrajac and colleagues (23) found five different factors applied for conversion of GH data from $\mathrm{mU} / \mathrm{l}$ to $\mu \mathrm{g} / \mathrm{l}$ in four major articles in a leading endocrine journal, all published within 5 years.

The heterogeneity of GH assay results is not only an academic problem for scientists, laboratories or clinical chemists. Several studies have shown that difficulties in comparing GH concentrations obtained by different assays have major impact upon clinical decisions, and therefore are relevant confounders in optimizing patient care (24-26). When directly comparing results from different assays in the same clinical samples in one laboratory, disagreement between $\mathrm{GH}$ assay methods was confirmed. Furthermore, it was demonstrated that the application of cut-off values from consensus statements led to different clinical decisions than the application of method-specific cut-off values. For example, Markkanen and colleagues analyzed $71 \mathrm{GH}$ nadir samples from oral glucose tolerance tests performed in patients with acromegaly by two different immunoassays (26). For interpretation, they used the 'consensus criterion' of GH suppression $<1 \mu \mathrm{g} / \mathrm{l}$ for either assays, or they used method-specific cut-off values derived from tests in a cohort of healthy volunteers. Depending on the cut-off values used, the percentage of patients considered 'in remission' varied from 48.1 to $85.2 \%$ in males and 56.8 to $68.2 \%$ in females. The higher discrepancy in males is a consequence of the lower nadir values in healthy males compared with females. In another study in children with GH deficiency (27), peak samples from GH stimulation tests, which had been measured by local laboratories, were reassessed centrally. Based on the central laboratories GH results obtained by one reference assay, 36 out of 132 patients were categorized differently, with 35 patients changing into the GH-deficient group. The situation is of concern especially because the awareness of the problem is still limited, and through the introduction of large central laboratories many clinicians have little impact on where and with which assay samples are measured. A survey among the members of the European Society for Pediatric Endocrinology (28) revealed that only $63 \%$ of the participants knew their local GH assay, and even less against which standard their local assay was calibrated. It is noteworthy that the most frequently quoted cut-off values used for the interpretation of stimulation test results in the diagnosis of GH deficiency were $10 \mu \mathrm{g} / \mathrm{l}$ 
and $20 \mathrm{mU} / \mathrm{l}$ - regardless of which calibrator the local laboratory used!

In order to improve the comparability of study results from several centers, some authors recommend the central reassessment of samples by a defined $\mathrm{GH}$ assay method (27) - an approach that is obviously impractical for patient care on a daily basis. Several guidelines emphasize the need for 'method-specific cut-off values' $(1,29-31)$, but in real life for most of the assays presently used, there are no published studies or reference data available. In the context of differences in epitope specificity of the antibodies used in different assays, the concept of 'commutability' deserves attention (32). A practical application of this concept on $\mathrm{GH}$ assays has been reported recently (33): laboratories obtained aliquots from the so-called 'harmonization samples' (representing 'average patient samples'), which were measured by all laboratories and used to correct their respective $\mathrm{GH}$ assay results from other samples. Using this approach, between-laboratory variability for $\mathrm{GH}$ assay results for those samples could be reduced from $15 \%$ to $<7 \%$. For this concept, the availability of sufficient amounts of adequate harmonization samples is required, and the applicability in a larger international setting should be investigated.

An international collaborative published a summary of the discussions and identified possible first steps toward assay standardization more likely to be implemented $(34,35)$. The use of a single, recombinant calibrator for all GH assays (IS 98/574) and the reporting of all $\mathrm{GH}$ assay results in mass units $(\mu \mathrm{g} / \mathrm{l})$ of the recombinant calibrator are foreseen to be the first important steps toward standardization. Changing to a uniform standard preparation has been shown to lead to a significant reduction in between laboratory variability in $\mathrm{GH}$ assay results from above $35 \%$ to below 20\% (9). Support of the initiative came from some important journals in the field, which have decided to publish papers on $\mathrm{GH}$ data only if these are expressed in mass units of the most recent IS 98/574 $(34,35)$. Meanwhile, several manufacturers of GH assays announced adoption of the new recombinant calibrator, at least for the European market. Unfortunately, several manufacturers - including the market leader - did not implement the change in the calibrator in all countries at the same time. Thus, $\mathrm{GH}$ assays from the same manufacturer now are available with different calibrations in different European countries. If and when the corresponding change will be implemented for assays available on the US market is still unclear. Therefore, researchers must be careful in reporting the correct calibration for $\mathrm{GH}$ assays used at the time the samples from their studies have been measured. Furthermore, it remains a primary task for editors and reviewers of scientific journals to ensure that manuscripts reporting $\mathrm{GH}$ assay data contain a clear statement regarding the assay method, and also refer to appropriate cut-off values for dynamic tests. Meanwhile, also the International Federation of
Clinical Chemistry and Laboratory Medicine has put the issue of GH assays on the agenda by implementing a working group on $\mathrm{GH}$ assay standardization. The collaboration with clinical chemists is of importance because - as mentioned above - in many cases the hormone analyses are in some type of large centralized laboratory far away from the clinician.

As outlined above, there are problems with GH assays, which cannot be solved solely by using a single calibrator for all assays. It remains to be investigated to which degree the 'standardization of the standard' alone leads to a better comparability of GH assay results, and what the impact upon cut-off values and clinical decisions will be. It is very likely that future activities must address the issue of differences in epitope specificity of different antibodies used to measure a heterogenous substance like GH. From a practical point of view, presently there is no alternative to increasing the awareness of the problem. Knowledge about the GH assays used in each local laboratory and its properties with respect to the application of cut-off values remains mandatory for clinicians to avoid misinterpretation of $\mathrm{GH}$ assay results.

\section{Disclosure}

This paper forms part of a European Journal of Endocrinology supplement, supported by Ferring. The authors disclose: no potential conflicting relationship with Ferring. This article was subject to rigorous peer review before acceptance and publication.

\section{References}

1 Consensus guidelines for the diagnosis and treatment of adults with growth hormone deficiency: summary statement of the Growth Hormone Research Society Workshop on Adult Growth Hormone Deficiency. Journal of Clinical Endocrinology and Metabolism 199883 379-381.

2 Growth Hormone Research Society. Consensus guidelines for the diagnosis and treatment of growth hormone (GH) deficiency in childhood and adolescence: summary statement of the GH Research Society. Journal of Clinical Endocrinology and Metabolism 200085 3990-3993.

3 Growth Hormone Research Society and the Pituitary Society. Biochemical assessment and long-term monitoring in patients with acromegaly: statement from a joint consensus conference of the Growth Hormone Research Society and the Pituitary Society. Journal of Clinical Endocrinology and Metabolism 2004 89 3099-3102.

4 Wieringa GE \& Trainer PJ. Commentary: harmonizing growth hormone measurements: learning lessons for the future. Journal of Clinical Endocrinology and Metabolism 200792 2874-2875.

5 Popii V \& Baumann G. Laboratory measurement of growth hormone. Clinica Chimica Acta 2004350 1-16.

6 Strasburger CJ \& Bidlingmaier M. How robust are laboratory measures of growth hormone status? Hormone Metabolic Research 200564 (Suppl 2) 1-5.

7 Bidlingmaier F, Geilenkeuser WJ, Kruse R \& Rohle G. Our experience with quality control in current growth hormone assays. Hormone Metabolic Research 199136 (Suppl 1) 1-4.

8 Morsky P, Tiikkainen U, Ruokonen A \& Markkanen H. Problematic determination of serum growth hormone: experience from external quality assurance surveys 1998-2003. Scandinavian Journal of Clinical and Laboratory Investigation 200565 377-386. 
9 Tanaka T, Tachibana K, Shimatsu A, Katsumata N, Tsushima T, Hizuka N, Fujieda K, Yokoya S \& Irie M. A nationwide attempt to standardize growth hormone assays. Hormone Metabolic Research 200564 (Suppl 2) 6-11.

10 Seth J, Ellis A \& Al-Sadie R. Serum growth hormone measurements in clinical practice: an audit of performance from the UK National External Quality Assessment Scheme. Hormone Metabolic Research 199951 13-19.

11 Ekins R. Immunoassay standardization. Scandinavian Journal of Clinical and Laboratory Investigation 1991205 (Supplement) 33-46.

12 Baumann G. Growth hormone heterogeneity: genes, isohormones, variants, and binding proteins. Endocrine Reviews 199112 424-449.

13 Baumann G. Growth hormone heterogeneity in human pituitary and plasma. Hormone Metabolic Research 199951 2-6.

14 Baumann G, Stolar MW \& Buchanan TA. The metabolic clearance, distribution, and degradation of dimeric and monomeric growth hormone $(\mathrm{GH})$ : implications for the pattern of circulating GH forms. Endocrinology 1986119 1497-1501.

15 Chatelain P, Bouillat B, Cohen R, Sassolas G, Souberbielle JC, Ruitton A, Joly MO \& Job JC. Assay of growth hormone levels in human plasma using commercial kits: analysis of some factors influencing the results. Acta Paediatrica Scandinavica 1990370 56-61 (discussion 62).

16 Reiter EO, Morris AH, MacGillivray $\mathrm{MH}$ \& Weber D. Variable estimates of serum growth hormone concentrations by different radioassay systems. Journal of Clinical Endocrinology and Metabolism 198866 68-71.

17 Hayakawa M, Shimazaki Y, Tsushima T, Kato Y, Takano K, Chihara K, Shimatsu A \& Irie M. Metabolic effects of 20-kilodalton human growth hormone $(20 \mathrm{~K}-\mathrm{hGH})$ for adults with growth hormone deficiency: results of an exploratory uncontrolled multicenter clinical trial of 20K-hGH. Journal of Clinical Endocrinology and Metabolism 200489 1562-1571.

18 Baumann G. Growth hormone binding protein 2001. Journal of Pediatric Endocrinology and Metabolism 200114 355-375.

19 Amit T, Youdim MB \& Hochberg Z. Clinical review 112: does serum growth hormone $(\mathrm{GH})$ binding protein reflect human $\mathrm{GH}$ receptor function? Journal of Clinical Endocrinology and Metabolism 200085 927-932.

20 Ebdrup L, Fisker S, Sorensen HH, Ranke MB \& Orskov H. Variety in growth hormone determinations due to use of different immunoassays and to the interference of growth hormone-binding protein. Hormone Metabolic Research 199951 20-26.

21 Jansson C, Boguszewski C, Rosberg S, Carlsson L \& AlbertssonWikland K. Growth hormone $(\mathrm{GH})$ assays: influence of standard preparations, GH isoforms, assay characteristics, and $\mathrm{GH}$-binding protein. Clinical Chemistry 199743 950-956.

22 Hansen TK, Fisker S, Hansen B, Sorensen HH, Christiansen JS, Jorgensen JO \& Orskov H. Impact of GHBP interference on estimates of GH and GH pharmacokinetics. Clinical Endocrinology 200257 779-786.

23 Pokrajac A, Wark G, Ellis AR, Wear J, Wieringa GE \& Trainer PJ. Variation in GH and IGF-I assays limits the applicability of international consensus criteria to local practice. Clinical Endocrinology $2007 \mathbf{6 7} 65-70$.
24 Celniker AC, Chen AB, Wert RM Jr \& Sherman BM. Variability in the quantitation of circulating growth hormone using commercial immunoassays. Journal of Clinical Endocrinology and Metabolism $198968469-476$.

25 Granada ML, Sanmarti A, Lucas A, Salinas I, Carrascosa A, Foz M \& Audi L. Assay-dependent results of immunoassayable spontaneous 24-hour growth hormone secretion in short children. Acta Paediatrica Scandinavica 1990 370 63-70 (discussion 71).

26 Markkanen H, Pekkarinen T, Valimaki MJ, Alfthan H, KauppinenMakelin R, Sane T \& Stenman UH. Effect of sex and assay method on serum concentrations of growth hormone in patients with acromegaly and in healthy controls. Clinical Chemistry $2006 \mathbf{5 2}$ 468-473.

27 Hauffa BP, Lehmann N, Bettendorf M, Mehls O, Dorr HG, Partsch CJ, Schwarz HP, Stahnke N, Steinkamp H, Said E, Sander S \& Ranke MB. Central reassessment of GH concentrations measured at local treatment centers in children with impaired growth: consequences for patient management. European Journal of Endocrinology 2004150 291-297.

28 Juul A, Bernasconi S, Clayton PE, Kiess W \& DeMuinck-Keizer Schrama S. European audit of current practice in diagnosis and treatment of childhood growth hormone deficiency. Hormone Metabolic Research 200258 233-241.

29 Molitch ME, Clemmons DR, Malozowski S, Merriam GR, Shalet SM, Vance ML \& Stephens PA. Evaluation and treatment of adult growth hormone deficiency: an Endocrine Society Clinical Practice Guideline. Journal of Clinical Endocrinology and Metabolism $2006911621-1634$

30 Melmed S, Casanueva F, Cavagnini F, Chanson P, Frohman LA, Gaillard R, Ghigo E, Ho K, Jaquet P, Kleinberg D, Lamberts S, Laws E, Lombardi G, Sheppard MC, Thorner M, Vance ML, Wass JA \& Giustina A. Consensus statement: medical management of acromegaly. European Journal of Endocrinology 2005153 737-740.

31 GH Research Society. Consensus guidelines for the diagnosis and treatment of growth hormone $(\mathrm{GH})$ deficiency in childhood and adolescence: summary statement of the GH Research Society. Journal of Clinical Endocrinology and Metabolism 200085 3990-3993.

32 Miller WG, Myers GL \& Rej R. Why commutability matters. Clinical Chemistry 200652 553-554.

33 Ross HA. Reporting growth hormone assay results in terms of one consensus recombinant standard preparation offers less than optimal reduction of between-method variation. Clinical Chemistry and Laboratory Medicine 200846 1334-1335.

34 Trainer PJ, Barth J, Sturgeon C \& Wieringa G. Consensus statement on the standardisation of $\mathrm{GH}$ assays. European Journal of Endocrinology 2006155 1-2.

35 Sheppard MC. Growth hormone assay standardization: an important clinical advance. Clinical Endocrinology 200766 157-161.

Received 23 September 2008

Accepted 24 September 2008 